\title{
ANALISIS KESESUAIAN PENERAPAN SAFETY SIGN DI PT. TERMINAL PETIKEMAS SURABAYA
}

\author{
Febry Eka Saputra \\ PT. Wijaya Karya (PERSERO), Tbk \\ JL. DI Panjaitan Kav.9, Jakarta 13340 \\ Email: febry.eka-12@fkm.unair.ac.id
}

\begin{abstract}
Safety sign is the equipment contained in the work environment in order to protect and enhance the awereness of workers against potential dangers which are occur in the work environment. This research was conducted to find out the suitability of applying the safety sign on work environment based on ANSI Z535 standard. This Research is observational with cross sectional design. Data collection was done by direct observation using ANSI Z535 safety sign checklist within a certain time. There are 5 types of safety sign based on the ANSI Z535standard researched. They are danger sign, warning sign, sign, sign the notice caution and safety condition sign. Field observation was retrieved results suitability against ANSI Z535 standard with highest suitability figures on danger sign fulfill 8 of 16 items (50\%), warning sign fulfill 6 out of 16 items (37.5\%), caution sign fulfill 9 out of 16 items (56.25\%), notice the sign fulfill 9 dari14 items (68.28\%), and safety condition sign fulfill the entire item (100\%). Conclusions on the research was application of a danger sign, warning sign, sign, and caution notice sign have not been suit with ANSI standard Z535. While the safety condition sign has been suit. HSSE management should have been did a monitoring, evaluation and improvement against the safety sign that damaged and did not suitable with the standards in International and Domestic Docks PT. Terminal Petikemas Surabaya.
\end{abstract}

Keywords: suitability, safety sign, ANSI Z535

\begin{abstract}
ABSTRAK
Safety sign adalah peralatan yang terdapat di lingkungan kerja guna melindungi dan meningkatkan kesiagaan pekerja terhadap potensi bahaya yang terdapat pada lingkungan kerja. Penelitian ini dilakukan untuk mengetahui kesesuaian penerapan safety sign pada lingkungan kerja berdasarkan standar ANSI Z535. Penelitian ini bersifat observasional dengan desain cross sectional. Pengumpulan data melalui observasi langsung mengunakan checklist safety sign ANSI Z535 dalam suatu saat tertentu. Terdapat 5 jenis safety sign berdasarkan standar ANSI Z535 yang diteliti antara lain danger sign, warning sign, caution sign, notice sign dan safety condition sign. Pada observasi lapangan diperoleh hasil kesesuaian terhadap standar ANSI Z535 dengan angka kesesuaian tertinggi pada danger sign memenuhi 8 dari 16 item (50\%,), warning sign memenuhi 6 dari 16 item (37,5\%), caution sign memenuhi 9 dari 16 item (56,25\%), notice sign memenuhi 9 dari14 item (68,28\%), dan safety condition sign memenuhi keseluruhan item (100\%). Kesimpulan pada penelitian ini adalah Penerapan danger sign, warning sign, caution sign, dan notice sign belum sesuai dengan standar ANSI Z535. Sedangkan safety condition sign telah sesuai. Disarankan pihak manajemen HSSE membuat suatu monitoring, evaluasi dan perbaikan terhadap safety sign yang telah rusak dan tidak memenuhi standar di Dermaga Internasional maupun Dermaga Domestik PT. Terminal Petikemas Surabaya.
\end{abstract}

Kata kunci: kesesuaian, safety sign, ANSI Z535

\section{PENDAHULUAN}

Kemajuan di bidang industri saat ini menjadi kian pesat di segala sektor. Kemajuan ini diiringi dengan penggunaan teknologi pada peralatan kerja dan material yang digunakan dalam kegiatan produksi. Beberapa aspek tersebut disertai tenaga kerjanya selalu melekat pada suatu kegiatan produksi. Beberapa aspek tersebut dapat menjadi sumber bahaya yang dapat mengakibatkan kecelakaan maupun penyakit akibat kerja. Risiko terjadinya kecelakaan dan penyakit akibat kerja dapat meningkat apabila didukung oleh lingkungan kerja yang tidak memenuhi syarat Keselamatan dan Kesehatan Kerja (K3), proses dan prosedur kerja tidak aman. (Pratama, et al., 2014)

Salah satu dari beberapa sektor industri tersebut adalah industri di bidang bongkar muat barang yang terdapat di dermaga pelabuhan. Kegiatan operasional yakni bongkar muat barang atau petikemas dilakukan di dermaga. Dermaga merupakan lokasi pelabuhan tempat kapal merapat dan melakukan kegiatan bongkar muat barang, serta menaikkan 
atau menurunkan penumpang. Suatu dermaga dibuat dengan menyesuaikan jenis dan ukuran kapal yang merapat pada lokasi tersebut. Hal tersebut digunakan untuk menunjang kelancaran kegiatan pengiriman barang atau petikemas menuju antarkota, antar provinsi, ekspor maupun impor. (Sukaarta, et al., 2012)

Kasus kecelakaan yang terjadi di industri bongkar muat barang tergolong cukup tinggi. Berdasarkan data Marine Department of Hongkong, kejadian kecelakaan yang tinggi terjadi di sektor bongkar muat petikemas di Hongkong. Tercatat kasus kecelakaan di sektor bongkar muat ini terjadi pada tahun 2010-2014. Tercatat pada tahun 2010 terjadi kasus kecelakaan sebanyak 167 kasus dengan 152 kasus menyebabkan kerugian yang bersifat minor, 9 kerugian serius dan 6 fatal. Pada tahun 2011 terjadi kenaikan jumlah kecelakaan dari tahun sebelumnya yakni 215 kasus kecelakaan dengan 197 kasus menyebabkan kerugian yang bersifat minor, 15 kerugian serius dan 3 fatal (Marine Department of Hongkong, 2015).

Berdasarkan data Marine Department of Hongkong, pada tahun pada tahun 2012, 2013, dan 2014 jumlah kecelakaan yang terjadi di sektor bongkar muat di Hongkong mengalami penurunan dari tahun 2011 meskipun masih tergolong tinggi yakni terjadi 126 kecelakaan dengan 96 kasus menyebabkan kerugian yang bersifat minor, 24 kerugian serius dan 6 fatal pada tahun 2012 (Marine Department of Hongkong, 2015).

Tahun 2013 terjadi 145 kecelakaan dengan 126 kasus menyebabkan kerugian yang bersifat minor, 15 kerugian serius dan 4 fatal (Marine Department of Hongkong, 2013). Sedangkan pada tahun 2014 tercatat terjadi 125 kasus kecelakaan dengan 102 kasus menyebabkan kerugian yang bersifat minor, 16 kerugian serius dan 7 fatal. Kasus kecelakaan tersebut menimbulkan efek minor, serius, maupun fatal (Marine Department of Hongkong, 2015).

Berdasarkan data lain dari Health Safety Executive United Kingdom tahun 2015, menunjukkan sepanjang tahun 2008-2013 terjadinya angka kecelakaan yang fluktuatif di sektor bongkar muat. Periode tahun 2008/2009 terjadi 425 kasus kecelakaan di industri tersebut. setelah itu, terjadi penurunan kasus pada periode 2009/2010 dengan 390 kasus kecelakaan, periode 2010/2011 dengan 295 kasus kecelakaan, serta periode 2012/2013 terjadi 220 kasus kecelakaan. Sedangkan kenaikan angka kecelakaan terjadi pada periode 2011/2012 terjadi 330 kasus kecelakaan yang lebih besar dari angka kecelakaan di tahun sebelumnya (HSE UK, 2013).

Berdasarkan data Administrator Pelabuhan Tanjung Perak Surabaya tahun 2010, kasus kecelakaan pelabuhan di Indonesia terjadi pada tahun 1995-2010. Beberapa kecelakaan tersebut terjadi di pelabuhan Tanjung Perak Surabaya. Kecelakaan tersebut mengakibatkan kerugian seperti kebakaran sebesar 7,56\%, tenggelamnya kapal sebesar 16,85\%, tabrakan antar kapal sebesar $37,15 \%$, kapal karam sebesar 7,34\%, muatan jatuh ke laut sebesar 4,97\%, mesin rusak sebesar $12,74 \%$, kapal hanyut sebesar $0,86 \%$, jangkar terputus sebesar $1,08 \%$, tidak terdata sebesar $2,59 \%$, dan lain-lain sebesar 2,81\% (Harahap, 2011). Kecelakaan kapal juga terjadi di Banten. Berdasarkan data Kantor Kesyahbandaran dan Otoritas Pelabuhan Kelas 1 Banten periode Desember 2012 hingga Januari 2014 , terdapat beberapa jenis kecelakaan antara lain tubrukan atau benturan, kebakaran, kandas dan tenggelam. Persentase kecelakaan tertinggi terdapat pada kecelakaan berupa tubrukan kapal dengan presentase sebesar $63,64 \%$ sebanyak 7 kejadian (Lady, et al., 2014). Sedangkan pada tenaga kerja di pelabuhan tercatat terjadi kecelakaan pada tahun 2007-2012, antara lain 13 kasus tahun 2007, 5 kasus tahun 2008, 3 kasus tahun 2009, 1 kasus tahun 2010, 3 kasus tahun 2011, dan 6 kasus tahun 2012 berlokasi di Pelabuhan Manado (Karlos, et al., 2014).

Sebelum terjadi sebuah kecelakaan, terdapat tahap-tahap yang memicu timbulnya kecelakaan tersebut. Berdasarkan Teori Domino W.F Heinrich, kecelakaan merupakan serangkaian proses hubungan sebab akibat. Kecelakaan tidak hanya disebabkan oleh satu faktor saja melainkan serangkaian faktor yang memiliki hubungan sebab akibat yang saling terkait. Berdasarkan teori domino yang dikembangkan oleh Frank Bird, kecelakaan diawali karena adanya lack of control terkait program dan standard yang digunakan. Kemudian dilanjutkan dengan sebab dasar (basic cause) misalnya penerapan yang tidak sesuai standar atau tidak adanya safety sign terkait penggunaan APD tertentu di lingkungan kerja. Hal tersebut dapat menimbulkan kurangnya kesiagaan pekerja serta pemikiran yang salah tentang safety sign sehingga arahan atau pesan yang terdapat pada safety sign tidak dapat diterima oleh pekerja. Pada akhirnya, hal ini berisiko menimbulkan kecelakaan (Ramli, 2010).

Kecelakaan yang terjadi akibat pekerjaan baik lingkungan kerja atau proses produksi harus 
ditanggung oleh perusahaan. Semakin banyak kecelakaan kerja yang timbul maka semakin besar pula kerugian yang dialami oleh perusahaan (Waruwu, et al., 2016). Kecelakaan kerja dapat menyebabkan kerugian langsung (direct lost) maupun tidak langsung (indirect lost). Kerugian langsung berupa biaya pengobatan pekerja yang mengalami kecelakaan dan biaya perbaikan kerusakan sarana produksi. Kerugian tidak langsung berupa kerugian jam kerja hilang, kerugian produksi, kerugian sosial dan menurunnya citra perusahaan serta kepercayaan konsumen (Septiana, 2014).

Menurut Basuki dkk (2015), kecelakaan di lingkungan kerja bersifat preventable (dapat dicegah). Pencegahan tersebut dapat dilakukan menggunakan prinsip manajemen antara lain perencanaan, pengorganisasian, pelaksanaan, pengawasan dan pengendalian serta evaluasi dan tindak lanjut. Sumber bahaya yang berisiko menimbulkan kecelakaan dapat dianalisis kemudian dirumuskan tindakan pencegahan yang tepat. Upaya pencegahan kecelakaan kerja terdiri dari berbagai cara, salah satunya dengan menerapkan safety sign sesuai standar di tempat kerja.

Safety sign adalah peralatan berupa ramburambu, simbol atau tanda yang berfungsi untuk mengurangi risiko dari sumber bahaya yang terdapat di lingkungan kerja. Safety sign juga digunakan untuk mengidentifikasi sumber dan meningkatkan kewaspadaan pekerja baik yang terlihat maupun yang tidak terlihat tanpa menggunakan bahasa verbal (Ebens, 2007).

Safety sign memuat keterangan atau informasi mengenai sumber bahaya, situasi yang memungkinkan terjadinya bahaya, efek yang ditimbulkan dari bahaya tersebut, serta tindakan pencegahan untuk menanggulangi terjadinya sumber bahaya tersebut. Safety sign juga memberikan petunjuk baik berupa arahan maupun larangan untuk mengurangi atau risiko terjadinya sumber bahaya. Safety sign juga harus komunikatif sehingga dapat berfungsi secara efektif dalam pencegahan kecelakaan kerja maupun penyakit akibat kerja. (Arphorn et al., 2003).

PT. Terminal Petikemas Surabaya (TPS) merupakan perusahaan yang bergerak di bidang bongkar muat barang untuk melayani kebutuhan masyarakat pelayaran, serta kegiatan ekspor dan impor. PT. Terminal Petikemas menyediakan jasa pelayanan seperti jasa tambat kapal petikemas, bongkar muat petikemas, penumpukan petikemas ekspor maupun impor. Terminal Petikemas Surabaya juga menyediakan pelayanan penyediaan air tawar ke kapal, penanganan petikemas berpendingin (reefer), pelayanan pergudangan/Container Freight Station (CFS) serta pelayanan Rel kereta api. Selain itu, PT. Terminal Petikemas Surabaya juga merupakan terminal bongkar muat barang dengan komitmen perusahaan untuk menciptakan tempat kerja yang aman dan meminimalisir dampak dari pengoperasian terminal baik bagi pekerja maupun tamu. Hal ini terbukti dengan sertifikat-sertifikat yang telah diperoleh oleh TPS antara lain: ISO 9001: 2008 (Sistem Manajemen Mutu), ISO 14001:2008 (Sistem Manajemen Lingkungan), OHSAS 18001:2007 (Sistem Manajemen Kesehatan dan Keselamatan Kerja), Sertifikat Penerapan SMK3 berdasarkan PP RI No. 50/2012, ISO 28000:2007 (Sistem Manajemen Keamanan untuk Rantai Pasok), dan ISO 27001:2005 (Sistem Manajemen Keamanan Informasi).

Berdasarkan data sekunder yang diperoleh di PT. Terminal Petikemas Surabaya, masih terdapat beberapa insiden pada bulan Januari-Desember 2015 yang menyebabkan injury maupun non injury. Terdapat 183 insiden yang bersifat non-injuries atau tidak mengakibatkan kesakitan, 8 insiden yang bersifat medical treatment atau membutuhkan penanganan medis, sedangkan untuk insiden yang mengakibatkan kesakitan jangka panjang atau long term injuries serta kematian (fatalities) tidak terjadi.

Dari segi lokasi dari insiden yang terjadi, terdapat 15 insiden di Dermaga Internasional, 3 insiden di Dermaga Domestik, 4 insiden di CY Export, 6 insiden di Gate, 1 insiden di gedung. Hal ini menunjukkan insiden tertinggi terjadi di lokasi Dermaga serta risiko kecelakaan pada PT. Terminal Petikemas Surabaya masih tinggi meskipun sudah ada komitmen perusahaan untuk mencegah terjadinya insiden tersebut. Untuk itu, Perusahaan dapat melakukan beberapa upaya pencegahan kecelakaan antara lain dari segi administratif seperti penyuluhan dan edukasi terkait risiko bahaya di tempat kerja, edukasi terkait safety sign untuk menambah pengetahuan pekerja, menciptakan persepsi yang benar terkait safety sign, serta penempatan safety sign di tempat kerja yang memiliki potensi bahaya sesuai persyaratan yang telah ditetapkan.

Berdasarkan American National Standards Institute (ANSI) Z535 dalam Clarion (2013), safety sign yang ditempatkan di tempat kerja merupakan simbol visual dan grafis berisi pesan, peringatan 
serta isyarat yang dapat mengkomunikasikan informasi untuk menghindari bahasa yang tidak di mengerti oleh pekerja. Safety sign yang juga harus memiliki warna yang dapat menarik perhatian pekerja. Serta memuat lebih banyak informasi yang dapat membantu pekerja dalam melaksanakan keputusan terkait pekerjaannya dengan aman dan lebih baik.

American National Standards Institute (ANSI) Z535 digunakan sebagai pedoman dasar untuk penerapan safety sign di tempat kerja karena standar tersebut lebih efektif dalam mengkomunikasikan keamanan dalam pekerjaan dengan penggunaan simbol - simbol secara global yang bersifat komunikatif untuk mengatasi hambatan bahasa, menarik perhatian pekerja dalam pekerjaannya. Berdasarkan American National Standards Institute (ANSI) Z535 dalam Clarion (2013), standar tersebut mengandung konten yang lebih substantif yang menjelaskan bahaya dan bagaimana cara penanggulangan dari bahaya tersebut, yang pada akhirnya dapat membantu mencapai menurunkan cedera dan angka kecelakaan kerja yang terjadi pada pekerja.

Pada observasi pendahuluan yang dilakukan pada dermaga internasional dan domestik PT. Terimal Petikemas Surabaya, diketahui terdapat beberapa safety sign yang belum memenuhi standar. Safety sign tidak memenuhi standar tidak akan menyampaikan pesan dengan baik sehingga berisiko menimbulkan kecelakaan (Lesch, 2003). Oleh karena itu, dibutuhkan analisis terkait kesesuaian penerapan safety sign tersebut.

Penelitian ini bertujuan untuk menganalisis kesesuaian penerapan safety sign di PT. Terminal Petikemas Surabaya dengan mengacu pada American National Standards Institute (ANSI) Z535 dalam Clarion (2013). Dengan diketahuinya kesesuaian safety sign berdasarkan standar tersebut dapat dirumuskan saran dan masukan kepada perusahaan terkait safety sign sesuai standar sehingga membuat fungsi safety sign lebih efektif, komunikatif, dan optimal untuk mencegah terjadinya kecelakaan kerja pada pekerja di lingkungan kerja. Penerapan safety sign sesuai American National Standards Institute (ANSI) Z535 dalam Clarion (2013), juga dapat mempertahankan atau bahkan meningkatkan proper perusahaan.

\section{METODE}

Metode pengumpulan data yang digunakan pada penelitian ini bersifat observasional karena peneliti tidak memberikan intervensi kepada sampel yang diteliti, namun hanya mengidentifikasi kesesuaian variabel yang diteliti terhadap standar yang dijadikan pedoman. Sedangkan berdasarkan waktu penelitian, penelitian ini bersifat cross sectional yaitu pengambilan data berdasarkan variabel yang diteliti dilaksanakan secara bersamaan pada suatu saat tertentu.

Penelitian ini dilakukan di Dermaga Internasional dan Dermaga Domestik PT. Terminal Petikemas Surabaya tepatnya Jl. Tj. Mutiara No. 1, Krembangan, Kota SBY, Jawa Timur. Lokasi tersebut dijadikan sebagai lokasi penelitian dikarenakan jumlah insiden tertinggi yang terjadi pada PT. Terminal Petikemas Surabaya berada di lokasi tersebut.

Waktu pengumpulan data pada penelitian ini dilaksanakan pada bulan Februari-Maret 2016. Pengambilan data pendahuluan dilaksanakan pada bulan Februari 2016, sedangkan pengambilan data melalui observasi lapangan pada bulan Maret 2016. Objek penelitian ini adalah safety sign yang terdapat pada area Dermaga Internasional dan Dermaga Domestik PT. Terminal Petikemas Surabaya.

Variabel yang diteliti dalam penelitian ini adalah pada aspek penerapan safety sign. Cara pengumpulan data diperoleh melalui checklist safety sign menurut American National Standards Institute (ANSI) Z535 dalam Clarion (2013). Terdapat jumlah item yang bervariasi pada tiap jenis safety sign yang diteliti antara lain danger sign sebanyak 16 item, warning sign sebanyak 16 item, caution sign sebanyak 16 item, notice sign sebanyak 14 item, dan safety condition sign sebanyak 11 item. Beberapa item tersebut meliputi aspek bentuk fisik, header, latar belakang warna, informasi yang dimuat, penggunaan tanda baca, bahan yang digunakan, penempatan, jarak minimum, ukuran dan tinggi tulisan. Analisis data dilakukan dengan membandingkan penerapan safety sign di lapangan dengan standar tersebut memperhatikan item di dalamnya sehingga diperoleh kategori kesesuaian penerapannya tergolong baik, kurang, atau tidak baik. Penerapan safety sign termasuk dalam kategori tidak baik apabila tingkat kesesuaiannya terhadap standar sebanyak 
0,25-33,3\%. Sedangkan untuk kategori kurang baik dan telah baik tingkat kesesuaiannya sebesar 33,4$66,7 \%$ dan $66,8-100 \%$.

Data primer pada penelitian ini diperoleh dengan cara observasi langsung pada beberapa safety sign di lapangan menggunakan checklist American National Standards Institute (ANSI) Z535 dalam Clarion (2013). Sedangkan data sekunder yang diperoleh dari bagian Health Safety Security and Environment (HSSE) PT. Terminal Petikemas Surabaya pada penelitian adalah profil perusahaan dan catatan atau rekapitulasi insiden yang terjadi di perusahaan tersebut.

\section{HASIL}

PT. Terminal Petikemas Surabaya (TPS) merupakan terminal petikemas bertaraf internasional pertama di Surabaya yang dibangun sejak tahun 1992 (awalnya dengan nama Unit Terminal Petikemas/ UPTK). PT. Terminal Petikemas Surabaya dalam beberapa tahun pengoperasiannya telah memiliki reputasi sebagai sebuah Terminal Petikemas yang efisien dan efektif terhadap biaya, yang mampu melayani kebutuhan masyarakat pelayaran dan para importir dan eksportir di Indonesia Bagian Timur. PT. Terminal Petikemas Surabaya memiliki fasilitas dermaga sepanjang 1450 meter dan Lapangan Penumpukan Petikemas seluas 40 hektar berkapasitas untuk menangani lebih dari dua juta teus pertahun. Pada tahun 2004, untuk pertama kalinya PT. Terminal Petikemas Surabaya mampu menangani lebih dari satu Juta teus dalam tahun kalender.

Produktivitas PT. Terminal Petikemas Surabaya dipantau terus-menerus. Dalam lima tahun terakhir ini, penanganan kapal petikemas telah meningkat dua kali lipat, dan waktu balik truk (TRT) telah menurun sampai 50\%. Hal penting yang mendukung kesuksesan PT. Terminal Petikemas Surabaya berasal dari beberapa aspek antara lain, kinerja para pegawai Perusahaan dan para Kontraktornya. Perusahaan mengadakan pelatihan dan kursus pendukung guna memastikan peningkatan mutu layanan untuk pertumbuhan perekonomiannya.

PT. Terminal Petikemas Surabaya melaksanakan beberapa jenis pelayanan yang berkaitan dengan proses bongkar muat Petikemas. Kegiatan operasional di perusahaan tersebut antara lain pelayanan jasa tambat kapal petikemas (container vessel berthing service), bongkar muat petikemas (container loading/discharging service), penumpukan petikemas ekspor (exported container stacking service), pengiriman petikemas impor (imported container delivery service), penyediaan air tawar ke kapal (water supply to vessel service), penanganan petikemas berpendingin berupa pemantauan temperatur di lapangan penumpukan dan pelayanan plug/unplug di atas kapal (temperature monitoring service for reefer container at the Container Yard and plugging/unplugging service on the vessel). Selain itu, PT. TPS juga melaksanakan pelayanan pergudangan/CFS (Container Freight Station for $S=$ Stripping \& Stuffing) dan penyimpanan petikemas berpendingin (cold storage).

Kegiatan operasional PT. Terminal Petikemas Surabaya memiliki sumber bahaya akibat proses kerja maupun lingkungan kerja di lokasi tersebut. Sumber bahaya tersebut terbagi menjadi beberapa jenis antara lain bahaya akibat benda bergerak (kinetik), bahaya akibat beda diam (statis), bahaya fisik, bahaya elektrik, bahaya kimiawi, bahaya biologis, bahaya ergonomis. Bahaya kinetik berasal dari benda bergerak lurus/ftnear movement (RTG, Container Crane, mobil, Forklift, Head Truck), benda bergerak berputar/rofafton (roda, roda gigi, crane, gerinda. pulley, katrol), dan pengangkatan/ pengangkutan (beban terlalu berat/cepat). Bahaya statis berasal dari kerusakan perkakas/sarana kerja, dan jembatan/perancah ambruk. Bahaya fisik berasal dari pencahayaan, kebisingan, dan getaran. Bahaya elektrik berasal dari isolasi yang tidak sempurna pada peralatan yang menggunakan tenaga listrik. Sedangkan bahaya kimiawi dan biologis berasal dari debu, uap, gas, dan bahan kimia yang digunakan untuk kegiatan produksi, serta kuman, bakteri, virus, jamur dan rodent di lokasi kerja tersebut.

PT. TPS meningkatkan efektivitas penerapan safety sign dengan melakukan sosialisasi, monitoring dan perbaikan. Sosialisasi terkait safety sign dilakukan secara berkala pada beberapa kegiatan seperti safety talk, briefing pagi, safety alert yang dipimpin oleh safety supervisor dan difasilitatori oleh safety officer. Sosialisasi terkait safety sign juga dilaksanakan ketika safety induction yang dilaksanakan oleh departemen HSSE PT. Terminal Petikemas Surabaya. Pekerja maupun individu lain yang berada di lokasi kerja tersebut juga diberikan buku saku yang berisikan salah satunya berbagai jenis safety sign beserta fungsinya sehingga memudahkan pekerja maupun individu lain di lokasi tersebut untuk memahami informasi yang terdapat pada berbagai jenis safety sign. 
Monitoring safety sign dilakukan secara berkala di semua area PT. Terminal Petikemas Surabaya. Monitoring tersebut dilakukan oleh seluruh jajaran yang saling berkoordinasi antara lain safety officer, safety engineer, safety supervisor maupun direksi.

Perbaikan safety sign dilakukan apabila terdapat safety sign yang telah rusak berdasarkan laporan safety officer, safety engineer, safety supervisor maupun direksi. Perbaikan safety sign di PT. Terminal Petikemas Surabaya dilaksanakan secara berkala. Perbaikan tersebut dilakukan oleh vendor atau pihak ketiga yang telah ditunjuk oleh PT. Terminal Petikemas Surabaya melalui departemen HSSE.

Berdasarkan observasi lapangan pada penelitian ini, diperoleh hasil sebagai berikut.

Tabel 1. Kesesuaian Penerapan Danger Sign pada Dermaga Domestik dan Dermaga Internasional PT. Terminal Petikemas Surabaya dengan American National Standards Institute (ANSI) Z535.

\begin{tabular}{lcc}
\hline \multicolumn{1}{c}{ Lokasi } & Kesesuaian Item & \% \\
\hline Container Crane 11 & 7 dari 16 & $43,75 \%$ \\
Area sekitar & 7 dari 16 & $43,75 \%$ \\
Dermaga Domestik & & \\
Lantai 2 kantor & 8 dari 16 & $50 \%$ \\
CBO & & \\
Container Crane 2 & 6 dari 16 & $37,5 \%$ \\
\hline
\end{tabular}

Penerapan danger sign pada dermaga PT. Terminal Petikemas masih tergolong dalam kategori kurang baik. Dari 4 jenis danger sign yang diobservasi di lokasi Container Crane 11, area sekitar dermaga domestik, area lantai 2 kantor CBO, dan Container Crane 2 dermaga internasional PT. Terminal Petikemas Surabaya keempatnya menunjukkan kesesuaian dengan item-item yang terdapat pada American National Standards Institute (ANSI) Z535 dalam Clarion (2013), sebanyak $\leq$ $50 \%$. Danger sign pada Container Crane 11 memenuhi 7 dari 16 item atau 43,75\%, danger sign di area sekitar dermaga domestik memenuhi 7 dari 16 item atau $43,75 \%$, danger sign di area lantai 2 kantor CBO memenuhi 8 dari 16 item atau $50 \%$, serta Danger sign pada Container Crane 2 memenuhi 6 dari 16 item atau 37,5\%. Item-item yang tidak sesuai dengan American National Standards Institute (ANSI) Z535 dalam Clarion (2013), antara lain terkait penggunaan kata "DANGER" pada rambu-rambu keselamatan, latar belakang warna yang digunakan, keterangan yang dimuat, dan bahan yang digunakan.

Tabel 2. Kesesuaian Penerapan Warning Sign Dermaga Internasional PT. Terminal Petikemas Surabaya dengan American National Standards Institute (ANSI) Z535.

\begin{tabular}{lcc}
\hline \multicolumn{1}{c}{ Lokasi } & Kesesuaian Item & \% \\
\hline $\begin{array}{l}\text { Container Crane } 6 \\
\text { dan }\end{array}$ & 6 dari 16 & $37,5 \%$ \\
Container Crane 11 & & \\
\hline
\end{tabular}

Penerapan warning sign pada dermaga PT. Terminal Petikemas Surabaya masih tergolong dalam kategori kurang baik. Warning sign yang diobservasi di lokasi Container Crane 11 dermaga domestik dan Container Crane 6 dermaga internasional PT. Terminal Petikemas Surabaya keduanya menunjukkan kesesuaian dengan item-item yang terdapat pada American National Standards Institute (ANSI) Z535 dalam Clarion (2013), sebanyak 6 dari 16 item atau $37,5 \%$. Item-item yang tidak sesuai dengan American National Standards Institute (ANSI) Z535 dalam Clarion (2013), antara lain terkait penggunaan kata "WARNING" pada ramburambu keselamatan, latar belakang warna yang digunakan, keterangan yang dimuat, dan bahan yang digunakan.

Tabel 3. Kesesuaian Penerapan Caution Sign Dermaga Internasional PT. Terminal Petikemas Surabaya dengan American National Standards Institute (ANSI) Z535.

\begin{tabular}{lcc}
\hline \multicolumn{1}{c}{ Lokasi } & Kesesuaian Item & \% \\
\hline Area sekitar & 9 dari 16 & $56,25 \%$ \\
Dermaga & & \\
Internasional & & \\
\hline
\end{tabular}

Penerapan caution sign pada area sekitar dermaga Internasional PT. Terminal Petikemas Surabaya masih tergolong dalam kategori kurang baik. Caution sign yang diobservasi di lokasi tersebut menunjukkan kesesuaian dengan item-item yang terdapat pada American National Standards Institute (ANSI) Z535 dalam Clarion (2013), sebanyak 9 dari 16 item atau $56,25 \%$. Item-item yang tidak sesuai dengan American National Standards Institute (ANSI) Z535 dalam Clarion (2013), antara lain terkait penggunaan kata "CAUTION" pada rambu- 
rambu keselamatan, latar belakang warna yang digunakan, keterangan yang dimuat, dan bahan yang digunakan.

Tabel 4. Kesesuaian Penerapan Notice Sign pada Dermaga Domestik dan Dermaga Internasional PT. Terminal Petikemas Surabaya dengan American National Standards Institute (ANSI) Z535.

\begin{tabular}{|c|c|c|}
\hline Lokasi & Kesesuaian Item & $\%$ \\
\hline Container Crane 11 & 4 dari 14 & $28,57 \%$ \\
\hline Container Crane 6 & 6 dari 14 & $38,46 \%$ \\
\hline $\begin{array}{l}\text { Area sebelah kanan } \\
\text { kantor CBO }\end{array}$ & 9 dari 14 & $64,28 \%$ \\
\hline $\begin{array}{l}\text { Container Crane } 6 \\
\text { (berupa arahan) }\end{array}$ & 9 dari 14 & $64,28 \%$ \\
\hline $\begin{array}{l}\text { Area dekat Container } \\
\text { Crane } 20\end{array}$ & 7 dari 14 & $50 \%$ \\
\hline
\end{tabular}

Penerapan notice sign pada Container Crane dan di sekitar lokasi kerja dermaga internasional dan dermaga domestic PT. Terminal Petikemas Surabaya sebagian besar tergolong dalam kategori kurang baik dan sisanya tergolong dalam penerapan tidak baik. Notice sign yang diobservasi sejumlah 5 jenis yang terdapat di lokasi Container Crane 11, Container Crane 6, area sebelah kanan kantor CBO dermaga internasional, dan area dekat Container Crane 20 dermaga domestik PT. Terminal Petikemas Surabaya. Notice sign pada Container Crane 11 memenuhi 4 dari 14 item $(28,57 \%)$ sehingga termasuk dalam kategori penerapan yang tidak baik, sedangkan 4 jenis notice sign lainnya termasuk dalam kategori penerapan yang kurang baik.

Notice sign pada Container Crane 6 memenuhi 6 dari 14 item atau 38,46\%, notice sign di area sebelah kanan kantor CBO dermaga internasional memenuhi 9 dari 14 item atau 64,28\%, Notice sign berupa arahan pada Container Crane 6 memenuhi 9 dari 14 item atau 68,28\%, sedangkan notice sign pada area dekat Container Crane 20 dermaga domestik memenuhi 7 dari 14 item atau 50\%. Item-item yang tidak sesuai dengan American National Standards Institute (ANSI) Z535 dalam Clarion (2013), antara lain terkait penggunaan kata "NOTICE" pada rambu-rambu keselamatan, latar belakang warna yang digunakan, keterangan yang dimuat, penempatan, bahan yang digunakan, jarak minimum, ukuran dan tinggi tulisan.
Tabel 5. Kesesuaian Penerapan Safety Condition Sign pada Dermaga Internasional PT. Terminal Petikemas Surabaya dengan American National Standards Institute (ANSI) Z535.

\begin{tabular}{lcc}
\hline \multicolumn{1}{c}{ Lokasi } & Kesesuaian Item & \% \\
\hline $\begin{array}{l}\text { Kantor CBO } \\
\text { Lantai } 2\end{array}$ & 11 dari 11 & $100 \%$ \\
\hline $\begin{array}{l}\text { Area sekitar Dermaga } \\
\text { Internasional }\end{array}$ & 10 dari 11 & $90,9 \%$ \\
\hline
\end{tabular}

Penerapan safety condition sign pada kantor CBO lantai 2 dan area sekitar dermaga internasional dermaga internasional PT. Terminal Petikemas Surabaya tergolong dalam kategori baik. Dari 2 jenis safety condition sign yang diteliti, keduanya menunjukkan kesesuaian dengan item-item yang terdapat pada American National Standards Institute (ANSI) Z535 dalam Clarion (2013) masing-masing sebanyak 10 dari 11 item atau 90,9\% dan 11 dari 11 item atau 100\%. Sebagian besar item American National Standards Institute (ANSI) Z535 dalam Clarion (2013) telah sesuai. Ketidaksesuaian hanya terdapat pada 1 dari 2 jenis safety condition sign yang diteliti karena terbuat dari material yang tahan lama.

\section{PEMBAHASAN}

\section{Analisis Penerapan Danger Sign}

Berdasarkan American National Standards Institute (ANSI) Z535 dalam Clarion (2013), suatu danger sign harus tercantum kata "DANGER" berwarna putih dengan kolom berlatar belakang berwarna merah. Danger sign tersebut harus memuat keterangan seperti sumber bahaya apa yang terdapat pada lokasi tersebut, efek yang ditimbulkan dari sumber bahaya tersebut, serta cara penanggulangannya. Keterangan yang dicantumkan tersebut berwarna hitam menggunakan kalimat aktif yang singkat serta dilengkapi tanda baca yang jelas. Pada keterangan tersebut ditambahkan juga pictogram atau gambar dengan kolom berlatar belakang warna putih. Sedangkan terkait bahan yang digunakan, bahan tersebut haruslah bersifat tahan lama seperti akrilik dan aluminium.

Penerapan danger sign di dermaga PT. Terminal Petikemas Surabaya sebagian besar masih belum mencantumkan kata "DANGER" berwarna putih. Pada item Latar belakang warna yang digunakan, danger sign pada dermaga PT. Terminal Petikemas 
Surabaya menggunakan warna merah di seluruh bagian, warna kuning, warna hitam, bahkan ada yang warnanya putih keabu-abuan karena telah terkelupas. Pada item keterangan, masih belum dicantumkan keterangan terkait efek yang ditimbulkan oleh sumber bahaya dan cara penanggulangannya. Sedangkan pada item bahan yang digunakan, pada danger sign tersebut sebagian besar menggunakan bahan yang tidak tahan lama yakni stiker atau skotlet dan hanya 1 danger sign yang menggunakan bahan akrilik dari 4 danger sign yang diobservasi.

\section{Analisis Penerapan Warning Sign}

Berdasarkan American National Standards Institute (ANSI) Z535 dalam Clarion (2013), suatu warning sign harus tercantum kata "WARNING" berwarna hitam dengan kolom berlatar belakang berwarna orange. Dalam Warning sign tersebut dimuat keterangan seperti sumber bahaya apa yang terdapat pada lokasi tersebut, efek yang ditimbulkan dari sumber bahaya tersebut, efek yang ditimbulkan dari sumber bahaya, serta cara penanggulangannya dengan penggunaan APD sesuai sumber bahaya. Pada keterangan tersebut dicantumkan pictogram atau gambar untuk memperjelas informasi yang disampaikan. Pesan yang dimuat berwarna hitam menggunakan kalimat aktif yang singkat dan dilengkapi tanda baca yang jelas. Sedangkan terkait bahan yang digunakan, bahan tersebut haruslah bersifat tahan lama seperti akrilik dan aluminium.

Penerapan warning sign di Container Crane 11 dermaga domestik dan Container Crane 6 dermaga internasional PT. Terminal Petikemas Surabaya masih belum mencantumkan kata "WARNING" berwarna hitam. Pada item Latar belakang warna yang digunakan, warning sign tersebut menggunakan warna belang garis-garis perpaduan antara hitam dan kuning. Pada item keterangan, masih belum dicantumkan keterangan terkait efek yang ditimbulkan oleh sumber bahaya dan penggunaan APD apa yang digunakan untuk penanggulangannya. Sedangkan pada item bahan yang digunakan, pada warning sign tersebut menggunakan bahan yang tidak tahan lama yakni stiker atau skotlet.

\section{Analisis Penerapan Caution Sign}

Berdasarkan American National Standards Institute (ANSI) Z535 dalam Clarion (2013), suatu caution sign harus memuat kata "CAUTION" berwarna hitam dengan kolom berlatar belakang berwarna kuning solid disertai pictogram atau gambar dan keterangan. Keterangan dan gambar yang dimuat di dalamnya berada dalam kolom berlatar belakang warna putih. Keterangan tersebut berwarna hitam dengan huruf awal capital, kalimat aktif dan bertanda baca. Keterangan tersebut memuat sumber bahaya yang terdapat pada lokasi tersebut, efek yang ditimbulkan dari sumber bahaya, serta cara penanggulangannya. Sedangkan terkait bahan yang digunakan, bahan tersebut haruslah bersifat tahan lama seperti akrilik dan aluminium.

Penerapan caution sign pada area sekitar dermaga internasional PT. Terminal Petikemas Surabaya telah mencantumkan kata "CAUTION" namun berwarna kuning dan memiliki latar belakang berwarna hitam. Caution sign di lokasi tersebut tidak memuat pictogram atau gambar. Keterangan yang dicantumkan pada caution sign juga masih kurang karena hanya mencantumkan cara penanggulangan sumber bahaya, tanpa mencantumkan sumber bahaya apa yang terdapat di lokasi tersebut dan efek yang ditimbulkan dari sumber bahaya.

\section{Analisis Penerapan Notice Sign}

Berdasarkan American National Standards Institute (ANSI) Z535 dalam Clarion (2013), suatu notice sign haruslah berbentuk kotak atau persegi panjang dengan kata "NOTICE" berwarna putih dan berkolom latar belakang warna biru. Notice sign tersebut dilengkapi dengan keterangan berupa larangan atau arahan, berkolom latar belakang putih, dan terdapat pictogram atau gambar. Keterangan tersebut ditulis dengan warna hitam, diawali huruf kapital dan disertai tanda baca yang jelas. Penempatan notice sign tersebut haruslah mudah terlihat dan tidak terhalang oleh objek atau benda apa pun sehingga mudah disadari dan terbaca oleh para pekerja. Penggunaan bahan atau material serta perpaduan jarak minimum, ukuran dan tinggi tulisan pada notice sign juga diperhatikan. Terkait bahan yang digunakan, haruslah terbuat dari bahan yang tahan lama seperti akrilik dan aluminium. Sedangkan jarak perpaduan jarak minimum, ukuran dan tinggi tulisan harus disesuaikan agar lebih efektif. Contohnya pada jarak 1,8 meter, tinggi huruf minimal haruslah $0,6 \mathrm{~cm}$ dengan ukuran huruf 31 poin atau $0,8 \mathrm{~cm}$.

Penerapan notice sign pada dermaga PT. Terminal Petikemas Surabaya masih belum mencantumkan kata "NOTICE" berwarna putih. Latar belakang warna yang digunakan berwarna merah, biru dan putih namun masih belum sesuai 
dengan standar. Penempatan notice sign di lokasi tersebut masih ada yang terhalang oleh kabel dan ditempatkan di sudut yang sulit terlihat pada Container Crane. Bahan yang digunakan pada notice sign tersebut terbuat dari besi, dan skotlet atau stiker. Sedangkan pada perpaduan jarak,, tinggi dan ukuran terdapat 4 dari 5 jenis notice sign yang belum sesuai dengan American National Standards Institute (ANSI) Z535.

\section{Analisis Penerapan Safety Condition Sign}

Berdasarkan standar American National Standards Institute (ANSI) Z535 dalam Clarion (2013), suatu safety condition sign harus terbuat dari bahan yang bersifat tahan lama seperti akrilik dan aluminium.

Penerapan safety condition sign pada yang belum sesuai dengan standar terdapat pada area sekitar Dermaga Internasional PT. Terminal Petikemas Surabaya karena menggunakan bahan dasar besi. Besi tidak termasuk dalam kategori bahan tahan lama dikarenakan mudah berkarat apabila ditempatkan pada lingkungan kerja outdoor akibat hujan maupun pengaruh iklim area tersebut.

\section{Analisis Kebutuhan Safety Sign Sesuai Standar ANSI Z535}

Berdasarkan analisis kesesuaian safety sign dengan American National Standards Institute (ANSI) Z535 dalam Clarion (2013), diperoleh hasil bahwa penerapan danger sign, warning sign, caution sign dan notice sign masih kurang baik. Sedangkan penerapan safety condition sign telah baik atau memenuhi standar. Aspek yang belum sesuai tersebut adalah pada header safety sign, latar belakang warna yang digunakan, keterangan yang dimuat, penempatan, bahan yang digunakan, jarak minimum, ukuran dan tinggi huruf.

Berdasarkan penelitian ini pihak manajemen HSSE disarankan untuk membuat suatu monitoring dan evaluasi terhadap penguatan dan kesesuaian safety sign di lingkungan kerja PT. Terminal Petikemas Surabaya. Terkait safety sign baik Dermaga Internasional maupun Dermaga Domestik yang telah rusak dan tidak memenuhi standar segera diperbaiki.

Perbaikan dilakukan dengan menambahkan header dan format safety sign baik danger sign, warning sign, caution sign dan notice sign di dermaga baik domestik maupun internasional sesuai dengan standar ANSI Z535. Perbaikan juga dilakukan pada latar belakang warna yang masih salah pada safety sign dengan melakukan rekondisi pada beberapa safety sign tersebut. Perbaikan atau rekondisi pada beberapa safety sign tersebut tidak harus dengan mengganti atau substitusi secara langsung. Selain membutuhkan dana yang besar, substitusi secara langsung dapat membahayakan pekerja karena pemasangannya membutuhkan waktu yang lama, sedangkan kegiatan operasional pada PT. Terminal Petikemas Surabaya dilaksanakan 24 jam atau terus menerus. Perbaikan atau rekondisi dapat dilakukan dengan mewarnai kembali safety sign yang warnanya telah terkelupas maupun pudar sesuai standar.

Informasi yang dimuat dalam safety sign harus dilengkapi sesuai standar ANSI Z535 dengan memuat sumber bahaya yang terdapat pada lingkungan kerja tersebut, efek yang ditimbulkan dari sumber bahaya dan cara penanggulangannya. Pada aspek penempatan safety sign, menurut Kerinci (2015), safety sign harus ditempatkan pada setiap unit atau bagian kerja supaya lebih efektif dalam pencegahan kecelakaan dan penyakit akibat kerja. Sedangkan menurut Zamami (2014). Pemasangan atau penempatan safety sign harus mudah terlihat dan ditempatkan pada setiap lokasi yang memiliki aktivitas kerja dan terdapat manusia di lokasi tersebut baik pekerja maupun tamu perusahaan. Penempatan safety sign yang menempel pada Container Crane dan sulit terlihat dipindahkan ke lokasi yang mudah terlihat yakni pada area pejalan kaki sebelah kiri dan kanan kantor CBO pada dermaga internasional, sedangkan pada dermaga domestik, lokasi safety sign dipindahkan ke area pejalan kaki depan Container Crane 2.

Bahan yang digunakan pada safety sign tersebut harus terbuat dari bahan yang tahan lama. Disarankan menggunakan bahan dasar akrilik atau aluminium pada safety sign tersebut. Sedangkan pada aspek jarak minimum, ukuran dan tinggi huruf pada safety sign yang masih belum sesuai, juga harus disesuaikan dengan standar ANSI Z535 supaya safety sign dapat berfungsi secara efektif, mudah terlihat dan mampu meningkatkan kewaspadaan para pekerja di lingkungan kerja tersebut.

\section{SIMPULAN}

Kesimpulan yang dapat diambil dari penelitian ini adalah Penerapan danger sign, warning sign, caution sign, dan notice sign berdasarkan American National Standards Institute (ANSI) Z535 termasuk 
dalam kategori kurang baik. Sedangkan penerapan safety condition sign berdasarkan American National Standards Institute (ANSI) Z535 termasuk dalam kategori baik.

Safety Condition sign yang telah sesuai dengan American National Standards Institute (ANSI) Z535 berlokasi di Kantor CBO lantai 2 Dermaga Internasional, sedangkan danger sign, warning sign, caution sign, dan notice sign yang belum sesuai terdapat pada Container Crane 11, Container Crane 6, area sekitar dermaga Internasional, Container Crane 2, area dekat Container Crane 20, area sebelah kanan kantor $\mathrm{CBO}$, dan area sekitar Dermaga Domestik.

Kebutuhan safety sign sesuai American National Standards Institute (ANSI) Z535 pada PT. Terminal Petikemas Surabaya adalah pada item-item yang belum sesuai dengan standar antara lain meliputi pada header safety sign, latar belakang warna yang digunakan, keterangan yang dimuat, penempatan, bahan yang digunakan, jarak minimum, ukuran dan tinggi huruf.

\section{DAFTAR PUSTAKA}

Arphorn, S., Augsornpeug, N., Srisorrachatr, S., Pruktharathikul, V. 2003. Comprehension of Safety Signs for Construction Workers: Comparison of Existing and Newly Designed Sign. Journal of Human Ergology, 32: pp. 87-94.

Basuki, M., Susanto, R. B., Herianto, H. P. 2015. Analisis Risiko Kegiatan Bongkar Muat sebagai Komponen Dwelling Time di Pelabuhan. Seminar Nasional Sains dan Teknologi Terapan III, pp: 511-518. Tersedia di: http://jurnal.itats.ac.id/wpcontent/uploads/2015/11/8.-minto-basuki_itats. pdf [diakses tanggal 27 Juli 2016]

Clarion. 2013. New OSHA/ANSI Safety Sign Systems (FOR TODAY'S WORKPALCES). [pdf] Milford: Clarion. Tersedia di: http://www.ishn.com/ext/ resources/Resources/white-papers/Clarion ISHN_Whitepaper.pdf [17 Oktober 2015].

Ebens, R. 2007. Designing Effective Machine Safety Signs. Occupational Hazards, pp. 29-30.

Harahap, R. G., Rosyid, D. M. 2011. Studi Peran Keandalan Manusia dalam Tubrukan Kapal (Studi Kasus Pelabuhan Tanjung Perak Surabaya). Digital Library ITS, pp. 1-10. Tersedia di: http:// digilib.its.ac.id/public/its-undergraduate-15373paper-pdf.pdf [diakses tanggal 27 Juli 2016]
Health Safety Executive UK. 2013. Statistics report for the Ports Industry 2012/13p (provisional). [pdf] UK: Health Safety Executive UK. Tersedia: http://www.hse.gov.uk/ports/port-industrystatistics-report-2012-13.pdf [10 December 2015].

Karlos, O.C., Josephus, J., Kawatu, P. 2014. Hubungan antara Aktivitas Fisik dengan Kelelahan Kerja pada Tenaga Kerja Bongkar Muat (TKBM) di Pelabuhan Manado. Tersedia di: http:// fkm.unsrat.ac.id/wp-content/uploads/2014/08/ HUBUNGAN_ANTARA_AKTIVITAS_FISIK_ DENGAN_KELELAHĀN_KERJA_PADA_ TENAGA_KERJA_BONGKAR_MUAT.pdf [diakses tanggal 27 Juli 2016]

Kerinci, A.N., Lumongga, N., Lubis, A.M. 2015. Hubungan Persepsi Keselamatan dan Kesehatan Kerja dengan Perilaku K3 pada Pekerja Bagian Produksi PT. Sumpratama Juru Engineering Medan Tahun 2015. Tersedia di: http://jurnal.usu. ac.id/index.php/lkk/article/download/10805/5762 [diakses tanggal 27 Juli 2016]

Lady, L., Marliana, P., Umyati, A. 2014. Kajian Kecelakaan Kapal di Pelabuhan Banten Menggunakan Human Factors Analysis and Classification System (HFACS). Jurnal Rekayasa Sistem Industri. 3 (2): pp. 46-52. Tersedia di: http://journal.unpar.ac.id/index.php/jrsi/article/ download/1296/1266 [diakses tanggal 27 Juli 2016]

Lesch, M. 2003. Comprehension and Memory For Warning Symbols: Age Related Differences and Impact of Training. Journal of Safety Research, 34: pp. 495-505.

Marine Department The Government of the Hong Kong, 2015. Casualties in Cargo Handling Accidents in 2010-2014. Hong Kong: Marine Department The Government of the Hong Kong. Tersedia di: http://www.mardep.gov.hk/en/ publication/ereport.html [10 Desember 2015].

Pratama, Y., Aulia, T. B., Nurisra. 2014. Identifikasi Faktor-Faktor Keselamatan dan Kesehatan Kerja (K3) yang Mempengaruhi Kinerja Proyek Konstruksi. Jurnal Teknik Sipil, 3 (3): pp. 218-226. Tersedia di: http://prodipps. unsyiah.ac.id/Jurnalmts/images/Jurnal/volume/ vol3/3.3.mts/21.218.226.Yudi\%20Pratama.pdf [diakses tanggal 27 Juli 2016]

Ramli, S. 2010. Sistem Manajemen Keselamatan dan Kesehatan Kerja OHSAS 18001. Jakarta: Dian Rakyat. 
Saputra, Febry E. 2016. Hubungan Pengetahuan Pekerja tentang Safety Sign dengan Persepsi Pekerja terhadap Kesesuaian Safety Sign di PT. Terminal Petikemas Surabaya. Skripsi. Surabaya: Universitas Airlangga.

Septiana, D. 2014. Hubungan Karakteristik Pekerja dengan Unsafe Action di PT. Pupuk Kalimantan Timur. Jurnal. Surabaya, ADLN Perpustakaan Universitas Airlangga.

Sukaarta, I.W., Sompie, B.F., Tarore, H. 2012. Analisis Resiko Proyek Pembangunan Dermaga Study Kasus Dermaga Pehe di Kecamatan Siau Barat Kabupaten Kepulauan Sitaro. Jurnal Ilmiah Media Engineering, 4 (4): pp. 257-226. Tersedia di: http://ejournal.unsrat.ac.id/index.php/jime/ article/download/4250/3779 [diakses tanggal 27 Juli 2016].
Waruwu, S., Yuamita, F. 2016. Analisis Faktor Kesehatan dan Keselamatan Kerja (K3) yang Signifikan Mempengaruhi Kecelakaan Kerja pada Proyek Pembangunan Apartement Student Castle. Jurnal Rekayasa Spectrum Industri. 14 (1): pp. 1-108. Tersedia di: http://journal.uad.ac.id/ index.php/spektrum/article/download/3705/1994 [diakses tanggal 27 Juli 2016]

Zamami, W. 2014. Identifikasi Bahaya Kecelakaan Unit Spinning I Menggunakan Metode Hirarc di PT. Sinar Pantja Djaja. Unnes Journal of Public Health, 3 (1) pp: 511-518. Tersedia di: http:// journal.unnes.ac.id/sju/index.php/ujph/article/ download/3162/2927 [diakses tanggal 27 Juli 2016] 